\title{
SOUTHERN OCEAN CURRENTS AND CLIMATE
}

\author{
by S. R. Rintoul
}

(with six text-figures; figures 2 and 6 in colour)

\begin{abstract}
Rintoul, S.R., 2000 (31:v): Southern Ocean currents and climate. In Banks, M.R. \& Brown, M.J. (Eds): TASMANIA AND THE SOLTHERN OCEAN. Pap. Proc. R. Soc. Tasm. 133(3): 41-50. https://doi.org/1 0.26749/rstpp. 133.3 .41 ISSN 0080-4703. CSIRO Marine Research and Antarctic Cooperative Research Centre, GPO Box 1538, Hobart, Tasmania, Australia 7001
\end{abstract}

The Antarctic Circumpolar Current (ACC) carries about 130 to $150 \times 10^{6} \mathrm{~m}^{3} \mathrm{~s}^{-1}$ along a $20000 \mathrm{~km}$ path circling Antarctica, making it the largest current in the world ocean. The flow of the ACC connects the ocean basins, allowing water, heat, and other properties to be carried fromone basin to another. The interbasin connection provided by the ACC is a key link in a global ocean circulation, sometimes called the "great ocean conveyor", which strongly influences the climate of the Earth on time-scales of years to centuries.

Unlike most other regions of the ocean, fluctuations of the currents play a central role in the heat and momentum budget of the Southern Ocean. The fluctuations carry momentum, supplied by the strong winds, down to where pressure forces against seafloor topography can compensate the wind forcing, and also carry heat poleward to balance the heat lost by the ocean to the cold atmosphere south of the ACC.

While the circumpolar current is the dominant circulation feature of the Southern Ocean, there are important flows in the north-south and vertical planes. Deep water shoals as it spreads south across the Southern Ocean, ultimately reaching the sea surface near Antarctica. Strong in teractions with the atmosphere and sea-ice modify the upwelled water where it reaches the surface: some water is made lighter by warming and freshening due to rainfall and sea-ice melt, while some is made more dense by cooling and addition of salt rejected during freezing of sea-ice. The water mass transformations driven by air-sea exchange in the Southern Ocean allow deep water to be converted to lighter intermediate water, as required to complete the loop of the global conveyor.

Key Words: Southern Ocean, climate, Antarctic Circumpolar Current, overturning circulation, temporal variability, water mass formation, eddy heat flux.

\section{INTRODUCTION}

While Douglas Mawson and his men endured consecutive winters at Commonwealth Bay on the Antarctic coast, the "Home of the Blizzard" (Mawson 1930), the members of the expedition who had returned to Hobart were fighting their own battlesagainst the elements. Edgar Waite, zoologist on the 1911-14 expedition, described their attempts to gather some of the first winter oceanographic observations in the Subantarctic Zone (Mawson 1940):

We had hoped against hope for weather fine enough to enable the trawl to be put over, but not a single day sufficiently favoured us; in fact, the whole tale of the cruise may be expressed as gales of wind, big seas, rain, snow and general gloom. On days when the seas were somewhat less tumultuous, sounding was essayed, but only three successful records were made. Considerable property was lost ... and 2,000 feet of sounding wire went to the bottom in an unorthodox manner.

Gathering oceanographic data from the Southern Ocean remains a challenging endeavour; log books of recent Southern Ocean expeditions contain their share of tales of "gloom" and "unorthodox" deployments of equipment.

The reputation of the Southern Ocean is built on experiences such as Waite's: mariners venture south with the expectation of encountering the strongest winds and largest waves to be found in the world ocean, but the Southern Ocean is also unique in the degree to which its currents affect both regional and global climate. It occupies the only band of latitudes where ocean waters circle the globe. This simple geographical fact turns out to have profound implications for the currents of the Southern Ocean and for their influence on the Earth's climate. Within this circumpolar channel lies the world's largest current, the Antarctic Circumpolar Current (ACC), which flows from west to east around the Antarctic continent, connecting the ocean basins to form a network of ocean currents known as the global overturning circulation, or "ocean conveyor". By transporting heat from one region to another, this global circulation is a vital $\operatorname{cog}$ in the heat engine which controls the Earth's climate. The link provided by the ACC allows anomalies formed in one basin to propagate to distant basins, where they affect regional and global climate (e.g. White \& Peterson 1996, Mikolawejicz \& Maier-Reimer 1990). (For a more complete overview of the influence of the ocean on global and Australian climate, see Piexoto \& Oort 1992, Rintoul et al. 1996 and Godfrey \& Rintoul 1998.)

Interactions between the ocean, atmosphere and sea-ice modify surface waters and cause them to sink and spread into the interior of the ocean. Southern Ocean water masses formed in this way renew a substantial fraction of the world ocean volume. Changes in the formation rate or properties of these water masses will change the rate at which the ocean stores heat, freshwater and gases such as carbon dioxide, thus influencing climate.

Southern Ocean currents also play an important role in the carbon cycle. Somewhat less than half of the carbon dioxide released to the atmosphere by human activities (primarily burning of fossil fuels and land clearing) remains in the atmosphere. The rest is taken up by the ocean or by land plants and soils, but the relative contributions of ocean and land are not well known. The Southern Ocean as a whole acts as a significant net "sink" of atmospheric carbon dioxide, although the exchange between the atmosphere and this ocean varies dramatically with location and season. The physical and biogeochemical processes 
which control this exchange are themselves controlled to a large degree by ocean currents. While the Southern Ocean contribution to the oceanic carbon cycle is an important part of the climate story, this issue will not be addressed here. Interested readers are referred to Sundquist (1993), Heimann (1993) and, for an Australian perspective, to Rintoul et al. (2000).

Th is paper reviews recent progress in understanding the link between Southern Ocean currents and climate, with an emphasis on work carried out in the Australian sector. Australia, and Tasmania in particular, has had a long historical connection to exploration and scientific expeditions to the Southern Ocean and Antarctica. For example, when Cook lowered anchor in what is now Adventure Bay on Bruny Island, he had already made several important observations of Southern Ocean currents, including the presence of a strong current setting his ship to the east between $40^{\circ} \mathrm{S}$ and $60^{\circ} \mathrm{S}$, and the surprising fact that water temperatures near Antarctica increased with depth near 100 fathoms $(200 \mathrm{~m})$, in contrast to all lower latitude oceans. This unusual temperature structure reflects the circulation of a "global ocean conveyor", as described in the final section of the paper.

\section{THE ANTARCTIC CIRCUMPOLAR CURRENT}

A broad-brush view of the mean global ocean circulation is shown in figure 1. The property plotted is "dynamic height", which serves as a streamfunction for ocean currents, much as pressure contours do for an atmospheric weather map: where the contour lines are close together, the currents are strong; where they are far apart, the currents are weak. Figure 1 illustrates the strength and circumpolar connection of the ACC. (Note that some important features of the ocean circulation such as intense boundary currents along the western side of the mid-latitude ocean basins are not well represented in the smoothed mean field shown here.)
Despite the importance of the ACC to the climate system, there have been few measurements of the current. Much of what we know about the ACC is derived from experiments conducted in Drake Passage in the late 1970s. These observations showed that the ACC consisted of a number of deep-reaching fronts or current jers which carried about $134 \times 10^{6} \mathrm{~m}^{3} \mathrm{sec}^{-1}$ to the easr (Nowlin \& Klinck 1986). More recently, hydrographic sections at other longitudes have confirmed the circumpolar extent of the fronts observed in Drake Passage (e.g. Orsi et al. 1995). Satellite measurements of sea surface temperature (e.g. Hughes et al. 1998; and fig. 2 opposite) and sea surface height (e.g Gille 1994) have revealed further details of the rich structure of the ACC fronts. The velocity measurements in Drake Passage also showed that fluctuations in the ACC, or "eddies", were important to the dynamical and thermodynamical balance of the ACC, as described in more detail below.

Because Drake Passage is the narrowest constriction through which the current must pass, and so may not be representative of the current as a whole, measurements were extended to other parts of the Southern Ocean during the World Ocean Circulation Experiment (WOCE). In particular, the most intensive measurements of the ACC made during WOCE were carried out south of Tasmania. These studies included ship-based observations, moored time series measurements, satellite remote sensing, and numerical experiments.

The centrepiece of the Australian studies of the ACC has been a hydrographic transect between Tasmania and Antarctica along roughly $140^{\circ} \mathrm{E}$ (WOCE line SR3), which has been occupied six times between 1991 and 1996 (Rintoul \& Bullister 1999, Rosenberg et al. 1995a, b, 1996). Upper ocean temperatures have been monitored along a nearby line from 1993 to the present as part of a joint Australia-France-USA program known as SURVOSTRAL (Rintoul et al. 1997). To orient the reader for the following discussion, a description of the major circulation features and water masses found on the SR3 transect is given here.

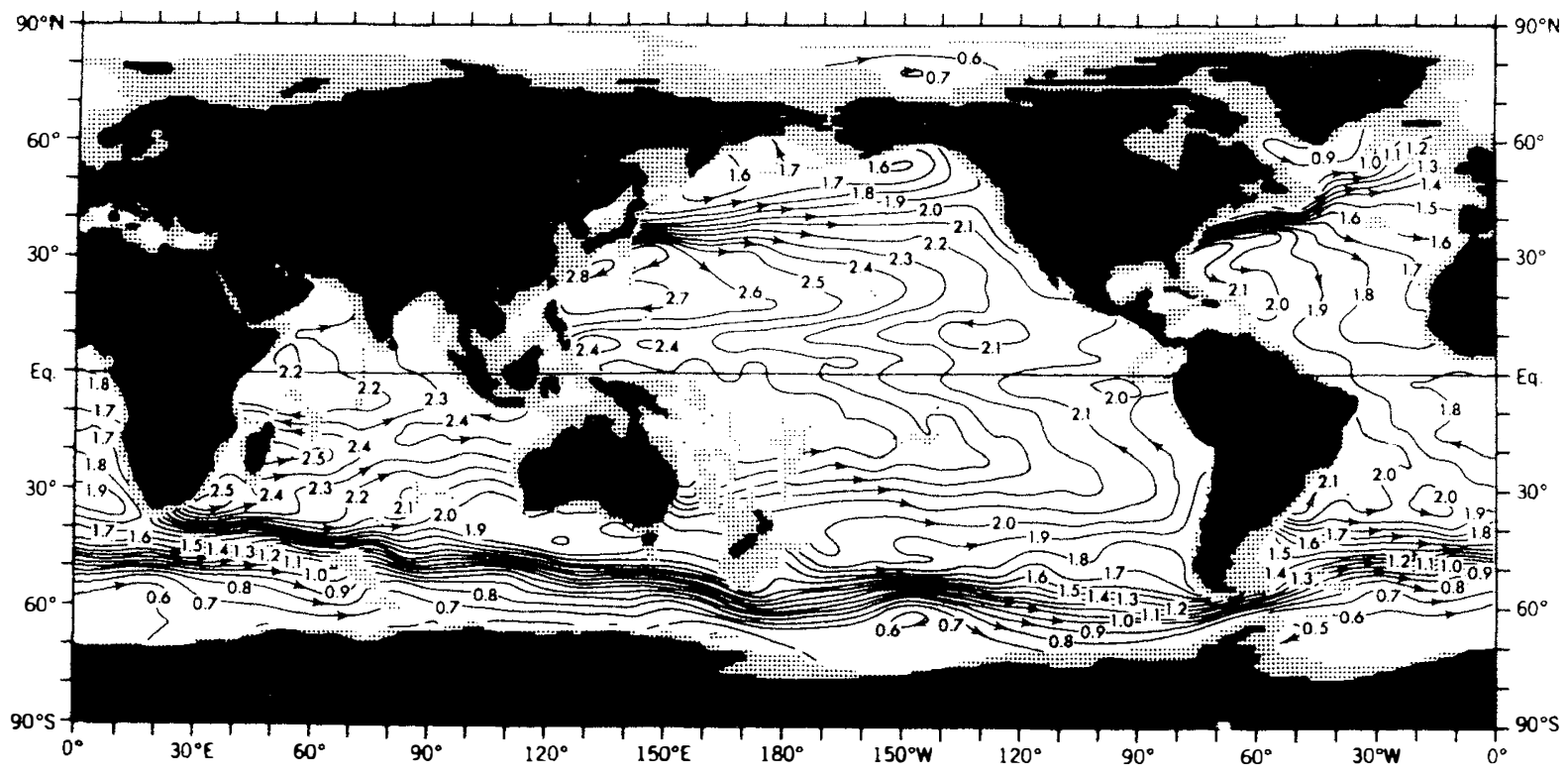

FIG. 1 - Annual mean dynamic height (anomaly of geopotential thickness, $10 \mathrm{~m}^{2} \mathrm{~s}^{-2}$ ) at the sea surface relative to $2000 \mathrm{~m}$ (from Levitus \& Boyer 1994). The arrows indicate the inferred direction of flow; the speed of the flow is inversely proportional to the spacing between the contours. 


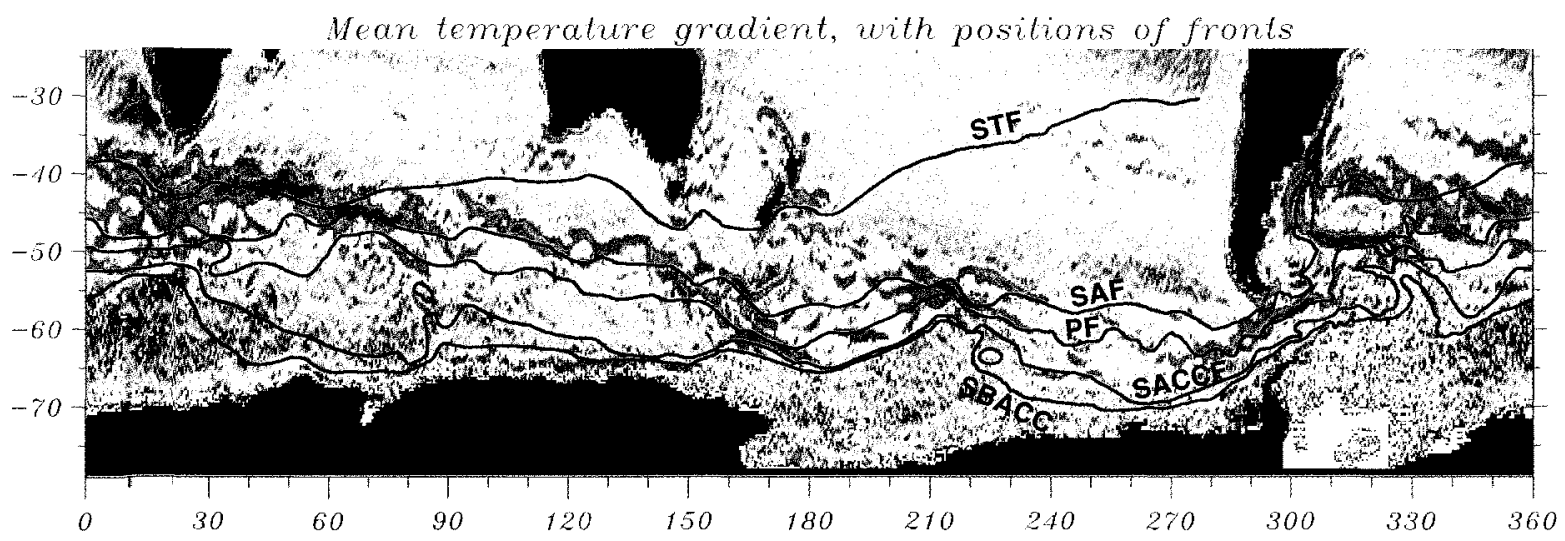

Contour Interval: 1.5 degrees $C$

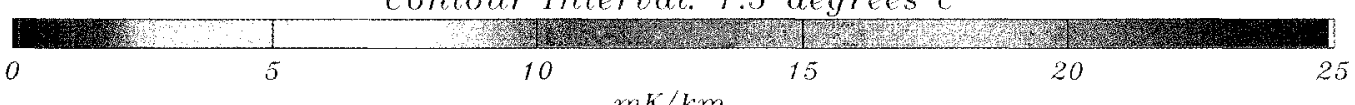

FIG. 2 - Magnitude of the mean sea surface temperature gradient, from 44 months of observations by the Along-Track Scanning Radiometer on the ERS-1 satellite (Hughes et al. 1998). Superposed are positions of (from north to south) the Subtropical Front $(S T F)$, Subantarctic Front (SAF), Polar Front (PF), Southern ACC Front (SACCF), and southern boundary of the ACC (SBACC), from Orsi et al. (1995).

Potential temperature along the transect, as measured in January 1995, is shown in figure 3A. The temperature of the water column generally decreases from north to south, reflected in the shoaling of isotherms to the south. The slope of the isotherms is particularly steep at a number of fronts, which are labelled at the top of figure $3 \mathrm{~A}$. These fronts circle the globe and separate zones where the water properties are more or less uniform. (For a discussion of the criteria used to identify the individual fronts, see Orsi et al. 1995 and Rintoul \& Bullister 1999.) The fronts correspond to jets of strong flow, which effect most of the transport by the ACC. The fronts evolve in time and are not stationary features: the section illustrated in figure $3 \mathrm{~A}$, for example, cuts across a meandering loop of the Subantarctic Front.

Figure $3 \mathrm{~A}$ is representative of summer conditions, when the surface layer has been warmed by the atmosphere. Below the warm summer mixed layer (pressures $>100 \mathrm{dbar}$ [ $1 \mathrm{dbar}$ is approximately equal to $1 \mathrm{~m}$ in depth]), remnants of the deeper winter mixed layers can be seen. The thick layer of uniform temperature $\left(8-9^{\circ} \mathrm{C}\right)$ between the Subtropical Front (at $46^{\circ} \mathrm{S}$ ) and the Subantarctic Front (at $51^{\circ} \mathrm{S}$ ) is produced by deep (> $500 \mathrm{dbar}$ ) convection in winter. The water mass produced by this deep winter mixing is known as Subantarctic Mode Water (see below). A temperature minimum layer is found south of $53^{\circ} \mathrm{S}$. This cold layer is also formed by convection driven by strong winter cooling. The warmer summer mixed layers are not as deep, and so a remnant layer of "winter water" is left, forming a temperature minimum between 100 and 250 dbar.

Salinity from the same transect is shown in figure $3 B$. The Subtropical Front separates saline subtropical water (salinity > $34.8 \mathrm{psu}$ ) from fresher subantarctic waters. Between the Subtropical and Subantarctic Fronts, the salinity minimum of the Antarctic Intermediate Water is found between 1000 and $1500 \mathrm{dbar}$. A salinity maximum, underlying the intermediate water, marks the Lower
Circumpolar Deep Water layer. The high salinity water originates in the northern Atlantic and spreads south, ultimately merging with the eastward flow of the ACC. At the southern end of the section, the thin layer of fresh, cold water found over the Antarctic continental slope is Antarctic Bottom Water.

As for salinity, the oxygen distribution along the transect shows a number of extrema which correspond to particular water masses (fig. 3C). The Subantarctic Mode Water forms a thick layer of high oxygen, as a result of exchange with the atmosphere during active convection in winter. The Antarctic Intermediate Water is also relatively high in oxygen but not as rich as the overlying mode water. An oxygen minimum layer indicates deep water which has been isolated from the sea surface for a long time. It is formed during long transits of the Indian and Pacific Oceans, and is known as Upper Circumpolar Deep Water once it returns to the Southern Ocean. The Antarctic Bottom Water is high in oxygen, reflecting the fact that this water has recently sunk from the sea surface.

Measurements of temperature and salinity (from which density can be calculated) can be used to determine the velocity at one depth relative to any other depth. If the velocity relative to the seafloor is integrated along the section, the mean net transport across the section is $143 \times 10^{6} \mathrm{~m}^{3} \mathrm{sec}^{-1}$ to the east, with a range from 131 to $158 \times 10^{6} \mathrm{~m}^{3} \mathrm{sec}^{-1}$ (fig. 4). The amount of water entering the Pacific basin south of Australia is about $10 \times 10^{6} \mathrm{~m}^{3} \mathrm{sec}^{-1}$ larger than that leaving the Pacific through Drake Passage. This extra eastward flow south of Australia is required to compensate the outflow from the Pacific to the Indian Ocean via the Indonesian passages. (Note that these estimates do not include the so-called "barotropic" part of the flow, which cannot be easily measured using ship-based instrumentation.)

Careful analysis of water property distributions indicates the origin of each of the current branches which cross SR3. By combining this information with recent transects to the 

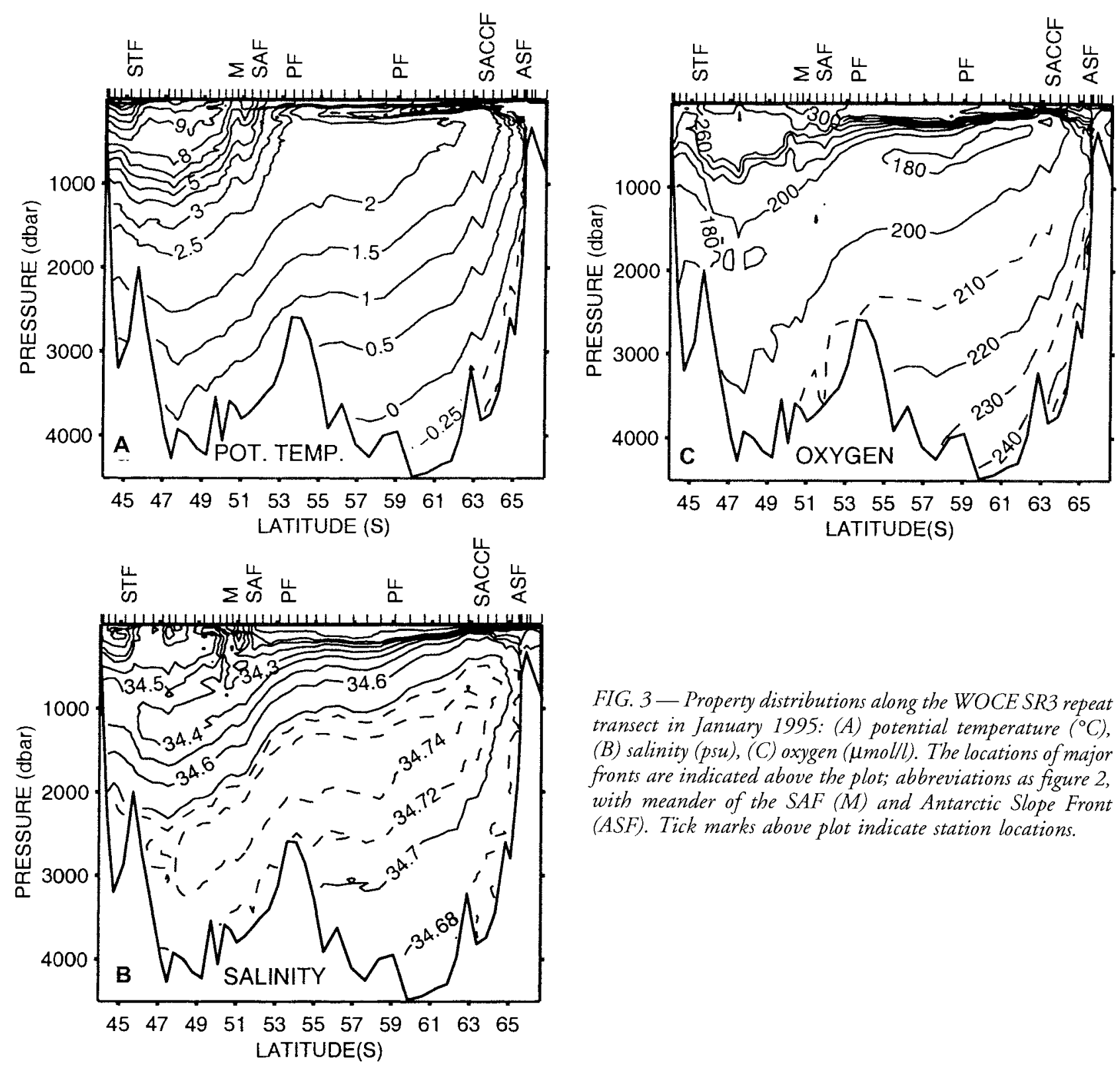

FIG. 3-Property distributions along the WOCE SR 3 repeat transect in January 1995: (A) potential temperature $\left({ }^{\circ} \mathrm{C}\right)$, (B) salinity ( $p s u),(C)$ oxygen ( $\mu$ molll). The locations of major fronts are indicated above the plot; abbreviations as figure 2 , with meander of the SAF (M) and Antarctic Slope Front (ASF). Tick marks above plot indicate station locations.

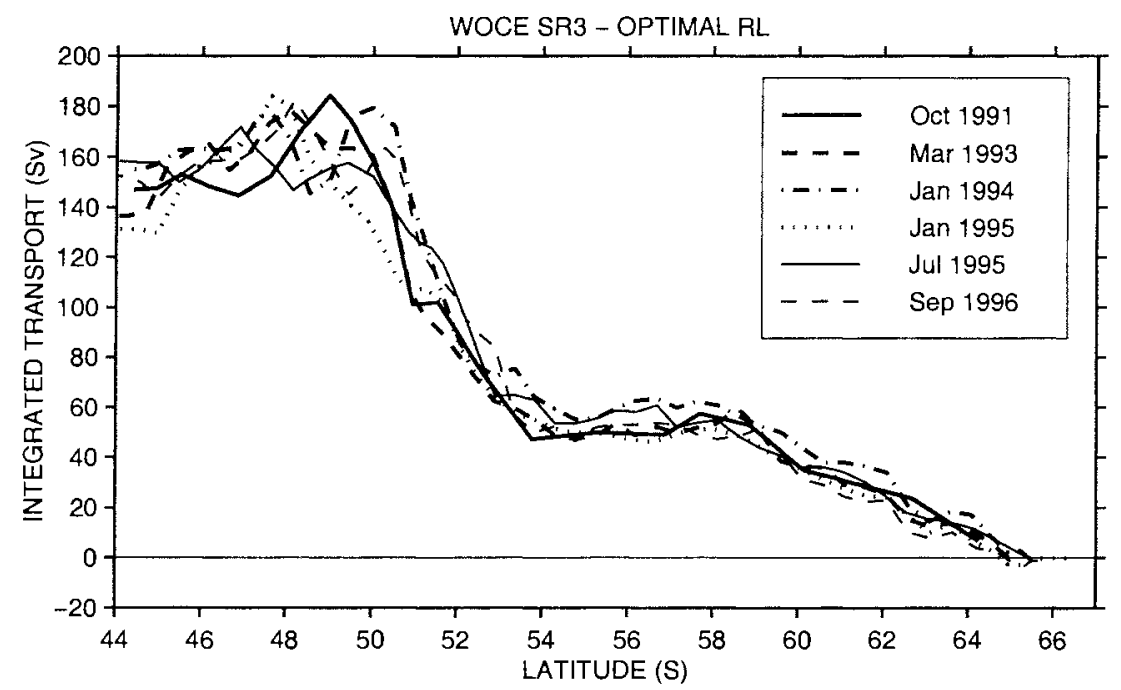

FIG. 4- Transport integrated from south to north for six occupations of the WOCE SR3 section, in units of $10^{6} \mathrm{~m}^{3} \mathrm{~s}^{-1}$. Positive values are toward the east. 
east and wist of SR3, and with climatological averages of historical lata, a sketch of the major currents south of Tasmania an be constructed (fig. 5). (The current paths in figure 5 rel in particular on WOCE sections P11S [Sokolov \& Rintoul2000] and P11A along $155^{\circ} \mathrm{E}$, the Olbers et al. [1992] atlis, and the SR3 repeat transects. The inferred flow path are also consistent with the trajectories of neutrally buoyant floats at $900 \mathrm{~m}$ depth [Davis 1999]. See Rintoul \& Sokolov [2000] for more details.) The mean transport ( $t 1$ standard deviation) of each of the currents crossing Sk3 is indicated in figure 5.
Some, but not all sections, show a strong westward flow immediately south of Tasmania. The temperature and salinity of this water indicates an origin in the Tasman Sea. Sokolov \& Rintoul (2000) showed that water enters the Tasman Sea from the south, mixes with subtropical water, and returns to the south adjacent to the coast of Tasmania. The transport of this branch (TAS, fig. 5) is $8 \pm 1310^{6} \mathrm{~m}^{3} \mathrm{~s}^{-1}$ to the west, the large standard deviation reflecting the highly variable nature of this flow. Further south, a deep-reaching, anti-clockwise gyre (SAZ) carries about $22 \pm 810^{6} \mathrm{~m}^{3} \mathrm{~s}^{-1}$. The low salinity and high oxygen of the intermediate water

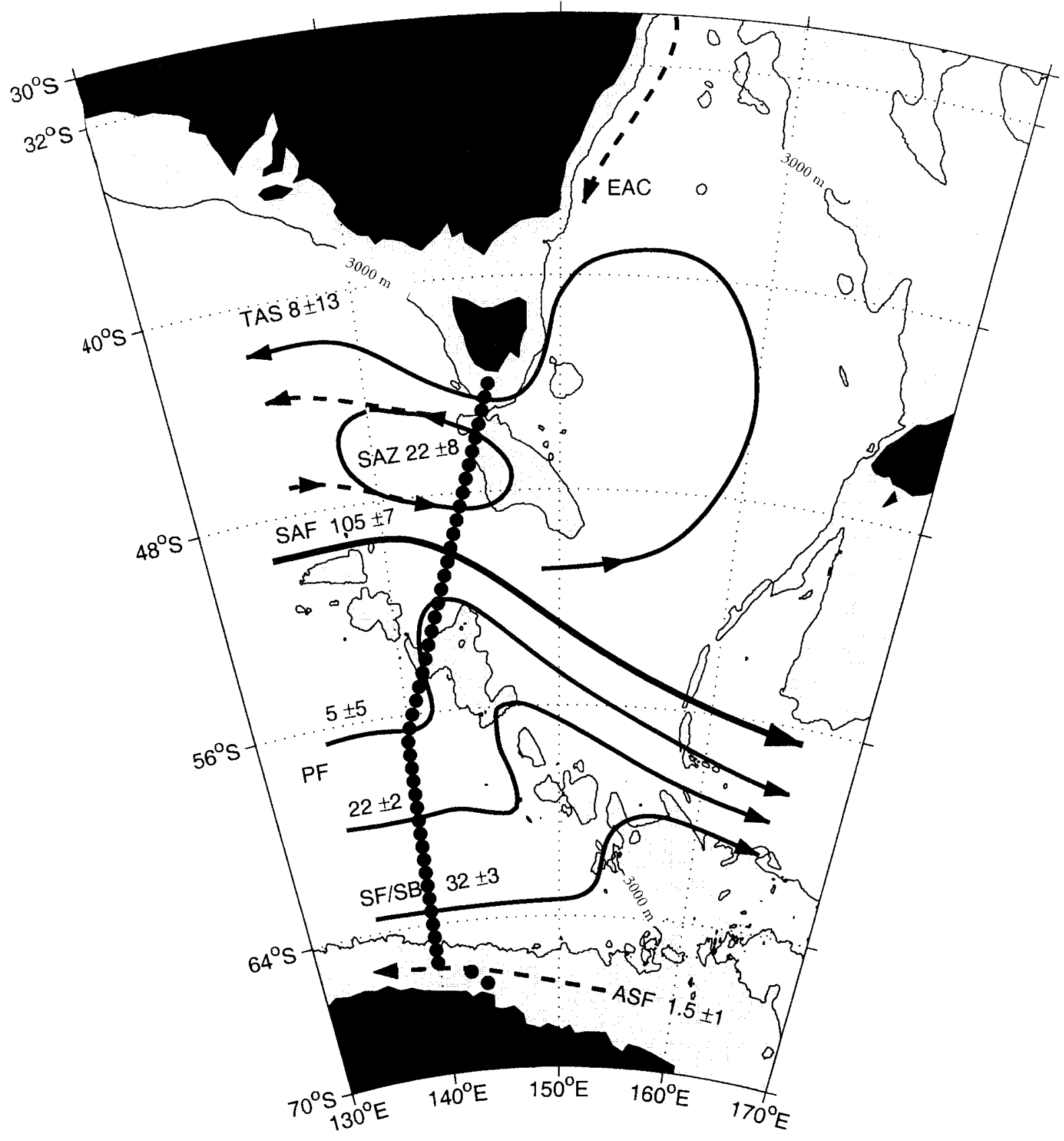

FIG. 5- A schematic view of the main currents south of Tasmania (see text for a description of the data on which the figure is based). The numbers give the mean ( \pm 1 standard deviation) transport of each current branch, based on the six repeats of SR3. $3000 \mathrm{~m}$ isobath is shown. 
in this gyre confirms that this is a local recirculation of southern-origin (i.e. not subtropical) water. The strongest current jet crossing SR3 is the Subantarctic Front, with a transport of $105 \pm 710^{6} \mathrm{~m}^{3} \mathrm{~s}^{-1}$. East of SR3, the front turns to the southeast, roughly parallel to the Southeast Indian Ridge. The Polar Front consists of two branches on each of the SR3 sections. The northern branch has a mean transport of $5 \pm 510^{6} \mathrm{~m}^{3} \mathrm{~s}^{-1}$, while the southern branch carries $22 \pm 210^{6} \mathrm{~m}^{3} \mathrm{~s}^{-1}$. Between the two expressions of the Polar Front the flow is weakly toward the west. Summing the transport in the two branches of the Polar Front and the westward flow between them gives a transport of $31{ }_{ \pm}$ 6) $10^{6} \mathrm{~m}^{3} \mathrm{~s}^{-1}$. Both fronts turn north when they encounter the shallower water over the ridge (as required to conserve poten tial vorticity), cross the ridge, and turn back to the southeast.

In figure 5, the two southernmost fronts associated with the ACC (the southern ACC front and the southern boundary of the ACC - Orsi et al. 1995) have been added together $(\mathrm{SF} / \mathrm{SB})$. The transport of the combined fronts is $32 \pm 310^{6} \mathrm{~m}^{3} \mathrm{~s}^{-1}$ to the east. The small standard deviations reflect the steadiness of the southern fronts of the ACC.

The repeats of SR3 provide the first detailed look at the variability of the ACC south of Australia, from the sea surface to the seafloor. Variability of upper ocean thermal structure in this region has also been described by Rintoul et al. (1997).

\section{DYNAMICS OF THE ANTARCTIC CIRCUMPOLAR CURRENT AND THE ROLE OF EDDIES}

The fact that the ocean is not blocked by land in the latitude band of Drake Passage has additional dynamical implications for the currents of the Southern Ocean. The fundamental balance of forces governing most open ocean flows is a balance between the Coriolis force and the pressure gradient force. To have net north-south flow in an ocean basin requires pressure differences in the east--west direction. In most ocean basins, land boundaries surrounding the ocean exist to support the required pressure gradients. In the circumpolar channel of the Southern Ocean, there can be no net pressure gradient in the east--west direction and, hence, no net north - south flow (except in thin frictional layers, or below the depth of bathymetric features like ocean ridges, which can support the required pressure gradients). The dynamics of the ACC differ from most other ocean currents and are still not completely understood. (See e.g. Warren et al. 1996, Hughes 1997, Olbers 1998, Warren et al. 1998 for a commentary on the on-going debate over ACC dynamics.)

One way in which the ACC differs from its lowerlatitude counterparts is in the central role that fluctuations in the current play in the dynamical and thermodynamical balance. Deviations from the east-west average current, frequently called "eddies", transfer the force of the wind blowing on the sea surface downward to the deep ocean. The momentum carried to the deep sea drives deep ocean currents, which establish pressure forces against the seafloor ridges to balance the momentum supplied by the wind (Munk \& Palmèn 1951). In other words, the driving force of the wind is compensated by a force exerted by the deep flow on seafloor topography; the deviations from a steady, strictly east-west flow act to transfer the momentum vertically through the water column. (Both variations in time and large-scale variations in space due to north-south shifts of the ACC axis contribute to the "eddy" fluxes.)

The eddies are important to the heat balance of the Southern Ocean, as well as the momentum balance. The ocean loses heat to the atmosphere south of the ACC but, due to the absence of land boundaries to support pressure gradients, there can be no poleward mean flow of warm water in the upper ocean to provide this heat (as e.g. the Gulf Stream does in the Atlantic). The poleward heat transport required to balance the heat lost to the atmosphere is instead carried by the eddy heat flux which results from correlations between velocity and temperature fluctuations. It turns out that eddies which carry heat poleward simultaneously carry momentum downward, so that the heat and momentum balances of the Southern Ocean are linked (Johnson \& Bryden 1989, Wolff et al. 1991).

Recently Australian scientists have deployed current meter moorings in the ACC to directly measure the eddy fluxes for the first time in this region. The current meter measurements confirm that the eddy heat flux is poleward, and that the eddies carry momentum downward through the water column, as required for the dynamical balance described above to hold (Phillips \& Rintoul 2000). Satellite measurements of sea surface height variability show clearly that eddy energy is enhanced along the entire path of the $\mathrm{ACC}$, and particularly so where the current interacts with sea floor bathymetry (e.g. Morrow et al. 1994).

Because of computer limitations, the present generation of climate models cannot explicitly resolve the small-scale eddies that play such a significant role in the dynamics and thermodynamics of the Southern Ocean. Instead, these eddies need to be parameterised in some way. New parameterisations of their effect on property transports dramatically improve the simulation of a number of features of the Southern Ocean: the temperature and salinity of the deep ocean, the depth of the mixed layer, and the depth to which chemical tracers entering from the atmosphere penetrate into the ocean (Gent \& McWilliams 1990, McDougall et al. 1996, Hirst \& McDougall 1996, England $\&$ Hirst, 1997). These improvements result in part because the parameterisation represents the dynamical instabilities of ocean currents more realistically, and in part because artificially large diffusivities are no longer required to keep the model stable (Hirst \& McDougall 1998). Correctly simulating these aspects of the ocean circulation is crucial if the model is to properly represent the processes by which the ocean absorbs, stores and transports heat and carbon dioxide. Models incorporating this parameterisation are therefore likely to provide more reliable predictions of climate change.

\section{THE GLOBAL OVERTURNING CIRCULATION AND WATER MASS FORMATION}

The strong eastward flow of the ACC carries water, heat and other properties between each of the Southern Hemisphere basins. In fact, the interbasin exchange provided by the ACC is at least an order of magnitude larger than all other interbasin flows combined. As a result, the ACC is an important link in the global pattern of ocean currents known as the "overturning circulation" (or "ocean conveyor"). 
To a lare extent, the properties of a given volume of sea water are determined when the water is in communication with the atmosphere at the sea surface, and these characteristic properties (e.g. temperature, salinity, oxygen concentration) are carried with the water parcel when it sinks in to the interior of the ocean. Away from the sea surface, the properties of sea water are only slowly modified by mixing with surrounding waters. The water characteristics obseryed in the interior of the ocean, therefore, reflect the properies where the water left the sea surface.

Most of the water in the ocean is cold (75\% of the ocean volume is cooler than $4^{\circ} \mathrm{C}-$ Worthington 1981) and, therefore, must have left the sea surface at high latitude, where cold surface temperatures are found. The sinking of cold, dense water at high latitudes of the North Atlantic and Southern Hemisphere is balanced by a return flow of warmer, lighter water to resupply the sinking regions. The flow of light water toward these regions, balanced by cold, dense water flowing away from them, forms the global overturning circulation. To close the loop, upwelling of deep water must occur somewhere to resupply the warm upper limb of the overturning circulation. Because the temperature difference between the deep and upper ocean limbs can be large, the overturning circulation can transport heat very efficiently and, hence, is an important part of the climate system. The sinking of dense surface water which has been in contact with the atmosphere also carries oxygen to the deep ocean: without sinking of deep and bottom water, there would be no oxygen in the deep sea.

The Southern Ocean plays several key roles in the overturning circulation. First, by connecting the ocean basins, the ACC allows such a global circulation pattern to exist. Second, the ACC transports deep water formed in the sinking regions to remote parts of the ocean. Third, the Southern Ocean is now believed to be the primary place where deep water is converted back to lighter water, as required to complete the loop.

The characteristic properties of about $50 \%$ of the world ocean volume are set through air-sea interaction in the Southern Ocean. These water masses are produced by an overturning circulation in the north-south plane (fig. 6). Relatively saline deep water, which originates in the North Atlantic, spreads to the south and shoals while being carried to the east by the strong flow of the ACC. (The presence of this relatively warm and salty water beneath the cool, fresh water in direct contact with the high-latitude atmosphere is responsible for the unexpected temperature inversion first noted by Captain Cook, as described in the Introduction.) Winds acting on the sea surface drive a divergence of surface waters which is balanced by upwelling of deep water. Some of the upwelled water is converted to denser bottom water (by cooling, mixing with cold but fresh water over the shelf, and the addition of salt released during freezing of sea-ice), while the remainder is converted

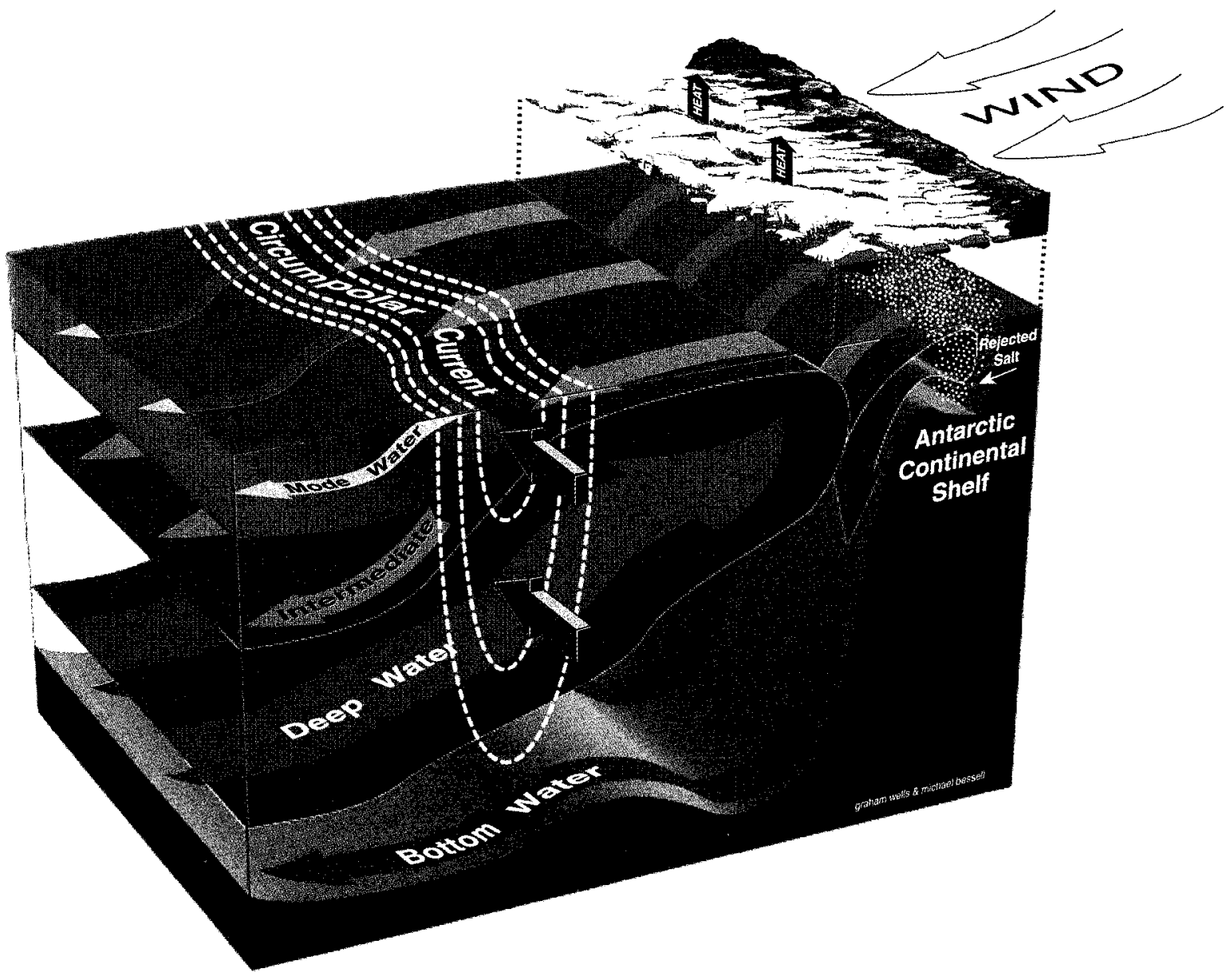

FIG. 6--A schematic view of the overturning circulation in the north-south plane in the Southern Ocean. Deep water upwells near Antarctica as a result of divergent wind-driven currents near the surface. Part of the upwelled deep water is driven north and converted to lighter intermediate and mode water by warming and freshening at the sea surface. The remainder is converted to denser Antarctic Bottom Water by cooling and addition of salt rejected during sea-ice formation. 
to less dense waters (by warming, and by freshening through precipitation and ice melt). Once formed, the Southern Ocean water masses spread to lower latitudes, where their relatively high oxygen concentrations "renew" the intermediate and abyssal waters of the world ocean.

This picture of the circulation in the meridional plane is largely unchanged from that first proposed by Sverdrup in the 1930s (Sverdrup 1933). Only recently have we been able to fill in some of the details, including where the deep and bottom water is formed, where it is converted to less dense water, and how the water masses participating in this loop may change with time.

With regard to sinking of dense water near Antarctica, we have found that the Antarctic coastline between $140^{\circ} \mathrm{E}$ and $150^{\circ} \mathrm{E}$ appears to be a much more significant source of bottom water than previously appreciated. A re-analysis of historical data suggests that up to $25 \%$ of the global inventory of Antarctic Bottom Water may be formed in this sector of the Antarctic coastline (Rintoul 1998); previous estimates had suggested $0.5 \%$ or less of the total is formed there (e.g. Carmack 1977). Bottom water formed in this region is high in dissolved gases such as oxygen and CFCs, and so is an important means of "ventilating" the deep ocean (Rintoul \& Bullister 1999). In particular, the water which fills the abyssal layers of the eastern Indian and Pacific Oceans is cold, fresh and high in oxygen, because of the influence of the bottom water formed between $140^{\circ} \mathrm{E}$ and $150^{\circ} \mathrm{E}$. (See Bindoff et al. [2000] for a more complete discussion of Antarctic Bottom Water formation.)

Some recent models suggest that most of the conversion of North Atlantic Deep Water to lighter intermediate water occurs in the Southern Ocean (e.g. Döö \& Coward,1997), rather than by upwelling distributed uniformly throughout the remainder of the world ocean, as traditionally assumed (e.g. Stommel \& Arons 1960). Upwelling of deep water at high latitude followed by warming and freshening at the sea surface forms Subantarctic Mode Water (SAMW) and Antarctic Intermediate Water (AAIW). Both of these water masses are renewed on decadal time-scales and can change relatively quickly in response to changes in the atmosphere. Recent work by Australian investigators has focused on these water masses in an attempt to document whether the interior of the ocean shows evidence of climate changes in recent decades.

Comparisons of recent data collected in the Tasman Sea, Indian and Southern Oceans with historical data collected mainly in the 1950s \& 1960s show that SAMW originating in the Southern Ocean has warmed in both the Indian Ocean and Tasman Sea, with maximum temperature increases of $0.5^{\circ} \mathrm{C}$ at $300 \mathrm{~m}$ (Bindoff \& Church 1992, Salinger et al. 1996). This significant warming is consistent with broad-scale warming of the surface waters where SAMW is formed (Bindoff \& McDougall 1994). Similar changes have now been observed throughout the Pacific Ocean (Wong et al. 1999). These analyses also show that AAIW near $1000 \mathrm{~m}$ depth has freshened, implying that the surface waters feeding the AAIW are now fresher than in the early 1960s. This freshening could be caused by an increase in rainfall between $50^{\circ} \mathrm{S}$ and $70^{\circ} \mathrm{S}$ fed by increased evaporation at low latitudes. The warming and freshening of the surface layers required to explain the observed temperature and salinity changes is consistent with the response of climate models to increasing concentrations of greenhouse gases (Bindoff \& McDougall 1994).

\section{SUMMARY}

Southern Ocean currents have a profound impact on the global ocean circulation, and hence the Earth's climate. The massive eastward flow of the ACC carries water, heat, salt and other properties between the ocean basins. Anomalies transported by the ACC can therefore influence the climate of regions remote from the location where the anomaly was created. Repeat transects between Tasmania and Antarctica have defined the transport of the main current branches south of Australia, and their variability, for the first time.

The dynamics of the ACC remain a topic of active debate. Direct current measurements south of Tasmania have quantified the rate at which fluctuations of the ACC, or "eddies", transport momentum downward and heat poleward, as anticipated from theory but not previously observed in the Australian sector. Recent advances in representing the effects of small-scale eddies on the largescale circulation have led to dramatic improvements in the ability of ocean models to simulate key features of the Southern Ocean.

The overturning circulation in the north-south plane, and the associated water mass transformations driven by air-sea fluxes, also play an important part in the climate system. Deep water formed in the North Atlantic spreads south and upward across the Southern Ocean, ultimately reaching the sea surface near Antarctica. The upwelled deep water is converted to both lighter and denser water masses which flow north to renew the intermediate and abyssal layers of the world ocean. In this way the Southern Ocean is a key link in the global overturning circulation which strongly influences the evolution of the climate system on time-scales of years to millennia.

\section{ACKNOWLEDGEMENTS}

I thank John Church, Nathan Bindoff and Mark Rosenberg for their valuable contributions to the organisation, fieldwork, and interpretation of the research summarised here. This work was supported by Environment Australia's Climate Change Research Program and the Antarctic Cooperative Research Centre. Assistance from the Australian National Antarctic Research Expeditions and the officers and crew of the RSV Aurora Australis is also gratefully acknowledged. This paper is a contribution to the World Ocean Circulation Experiment.

\section{REFERENCES}

Bindoff, N. L. \& Church, J. A., 1992: Warming of the water column in the southwest Pacific Ocean. Nature 357:59 62.

Bindoff, N. L. \& McDougall, T. J., 1994: Diagnosing climate change and ocean ventilation using hydrographic data. $J$. Phys. Oceanogr. 24: 1137-1152.

Bindoff, N.L., Rintoul, S.R. \& Massom, R., 2000: Bottom water formation and polynyas south of Tasmania. Pap. Proc. R Soc. Tasm. 133(3): 51-56.

CARMack, E.C., 1977: Water characteristics of the Southern Ocean south of the Polar Front. In Angel, M.V. (Ed.): A VOYAGE OF DISCOVERY: George Deacon 70th Anniversary Volume. Supplement to Deep-Sea Research. Pergamon Press: 15-37. 
DAVIS, R.E. 1999: Preliminary results from directly measuring middepth circulation in the tropical and South Pacific. J. Gophys. Res. 103: 24619-24640.

Doos, K. \& Coward, A., 1997: The Southern Ocean as the major upwelling zone of North Atlantic Deep Water. Int. WOCE Newsl. 27: 3-4.

ENGLAND, MH. \& HiRs, A.C., 1997: Chlorofluorocarbon uptake in a world ocean Model; 2: sensitivity to surface thermohalire forcing and subsurface mixing parameterization, J. Gophys. Res. 102: 15709-15731.

Gent, P.R. \& McWilliams, J.C., 1990: Isopycnal mixing in ocean circulation models. J. Phys. Oceanogr. 20: 150 155.

Gille, S.T., 1994: Mean sea-surface height of the Antarctic Circumpolar Current from GEOSA' 1 data - method and application. J. Geophys. Res. 99: 18255-18273.

Godfrey, J.S. \& Rintoul, S.R., 1998: The role of the oceans in southern hemisphere climate. In Karoly, D. \& Vincent, D. (Eds): METEOROLOGY AND OCEANOGRAPHY OF THE SOUTHERN HEMISPHERE. Meteorol. Monogr. 27. American Meteorology Society: 283-306.

Heimann, M., 1993: THE GLOBAL CARBON CYCLE. NATO ASI Series. Springer-Verlag, Berlin, Heidelberg.

Hrrst, A. C. \& McDougall, T. J., 1996: Deep-water properties and surface buoyancy flux as simulated by a z-coordinate model including eddy-induced advection. J. Phys. Ocecnogr. 26: 1320-1343.

Hirst, A.C. \& McDOUgall, T.J., 1998: Meridional overturning and dianeutral transport in a $z$-coordinate ocean model including eddy-induced advection. J. Phys. Oceanogr. 28: $1205-1223$.

HugHES, C.W., 1997: Comments on "On the obscurantist physics of 'form drag' in theorizing about the circumpolar current". J. Phys. Oceanogr. 27(1): 209-210.

Hughes, C.W., Jones, M., \& Carnochan, S., 1998: Use of transient features to identify eastward currents in the Southern Ocean. J. Geophys. Res. 103: 2929-2944.

Johnson, G.C. \& Bryden, H.L., 1989: On the size of the Antarctic Circumpolar Current. Deep-Sea Res. 36: 3953.

LeVITUS, S. \& BOYER, T., 1994: WORLD OCEAN ATLAS, 1994. Tech. rep., NOAA, Washington D.C.

MAWSON, D., 1930: HOME OF THE BLIZZARD. Abridged popular edition, facsimile edition published 1996. Wakefield Press, South Australia.

MAwson, D., 1940: Australasian Antarctic Expedirion, 1911 1914. SCIENTIFIC REPORTS, Series A, Vol. II: Oceanography.

McDougall, T.J., Hirst, A.C., England, M.H. \& Mcintosh, P.C., 1996: Implications of a new eddy parameterization for ocean models. Geophys. Res. Lett. 23: 2085-2088.

Mikolawejicz, U. \& Maier-Reimer, E., 1990: Internal secular variability in an ocean general circulation model. Clim. Dyn. 4: 145-156.

Morrow, R., Coleman, R., Church, J.A., \& Chelton, D., 1994: Surface eddy momentum flux and velocity variances in the Southern Ocean from GEOSAT altimetry. J. Phys. Oceanogr. 24: 2050-2071.

Munk, W.H. \& Palmien, E., 1951: Note on the dynamics of the Antarcric Circumpolar Current. Tellus 3: 53-55.

Nowlin, W.D., JR, \& KLINCK, J.M., 1986: The physics of the Antarctic Circumpolar Current. Rev. Geophys. Space Phys. 24: 469-491.

OlBERS, D., 1998: Comment on "On the obscurantist physics of 'form drag' in theorizing about the circumpolar current". J. Phys. Oceanogr. 28: 1647-1654.

Olbers, D., Gouretski, V., Seiss, G. \& Schroter, J., 1992 : HYDROGRAPHIC ATLAS OF THE SOUTHERN $O C E A N$. Alfred Wegener Institute, Bremerhaven: 17 pp., $82 \mathrm{pl}$.
Orst, A.H., WhITWORTh,T.W., III \& Nowlin, W.D., JR., 1995: On the meridional extent and fronts of the Antarctic Circumpolar Current. Deep-Sea Res, 42: 641-673.

Phillips, H.E., \& Rintoul, S.R., 2000: Eddy variability and energetics from direct current measurements in the Antarctic Circumpolar Current south of Australia. I. Phys. Oceanogr. (in press).

Piexoto, J.P. \& OORT, A.H., 1992: PHYSICS OF CLIMATE. American Institute of Physics, New York: $520 \mathrm{pp}$.

RinToul, S.R., 1998: On the origin and influence of Adelie Land Bottom Water. In Jacobs, S. \& Weiss, R., (Eds): OCEAN, ICE AND ATMOSPHERE: INTERACTIONS AT THE ANTARCTIC CONTINENTAL MARGIN. Antarct. Res. Ser. 75. American Geophysical Union, Washington: :151171.

Rintoul, S.R. \& BulLis IER, J.L., 1999: A late winter hydrographic secrion from Tasmania to Antarctica. Deep-Sea Res. I(46): $1417-1454$.

Rintoul, S.R. \& Sokolov, S., 2000: Baroclinic transport variability of the Antarctic Circumpolar Current south of Australia (WOCE repeat section SR3). J. Geophys. Res. (in press).

Rintoul, S.R., Meyers, G., Church, J.A., Godfrey, J.S., Moore, M. \& Stanton, B., 1996: Ocean processes, climate and sea level. In Bouma, W.J., Pearman, G. \& Manning, M. (Eds): GREENHOUSE: COPING WITH CLIMATE CHANGE. CSIRO Publishing: 127-144.

Rintoul, S.R., Donguy, J.-R. \& Roemmich, D., 1997: Seasonal evolution of upper ocean thermal structure between Tasmania and Antarctica. Deep-Sea Res. 44: 1185-1202.

Rintoul, S.R., Wolff, J.-O., Grifyrthe, B., Bindoff, N.L., Church, J.A., Tilbrook, B., Parslow, J. \& Rosenbera, M., 2000: Southern Ocean processes and climate: Recent progress by ANARE. In Marchant, H. (Ed.): THE SILENCE BROKEN: 50 YEARS OF ANARE SCIENCE. Australian Antarctic Division (in press).

RosenberG, M., Eriksen, R. \& Rintoul, S.R., 1995a: Aurora Australis marine science cruise AU9309/AU9391 Oceanographic field measurements and analysis. Res. rep. 2. Antarctic Cooperative Research Centre.

Rosenberg, M., Eriksen, R., Bell, S., Bindoff, N. L. \& Rintoul, S. R., 1995b: Aurora Australis marine science cruise AU9407 - Oceanographic field measurements and analysis. Res. rep. 6. Antarctic Cooperative Research Centre.

Rosenberc, M., Eriksen, R., Bell, S., \& Rintoul, S.R., 1996: Aurora Australis marine science cruise AU9404 Oceanographic field measurements and analysis. Res, rep. 8. Antarctic Cooperative Research Centre.

Salinger, M.J., Allan, R., Bindoff, N.L., Hannah, J., Lavery, B., Lin, Z., Lindesay, J., Nicholls, N., Plummer, N. \& TOROK, S., 1996: Observed variability and change in climare and sea-level in Oceania. In Bouma, W.J., Pearman, G. \& Manning, M. (Eds): GREENHOUSE: COPING WITH CLIMATE CHANGE. CSIRO Publishing: 100-126.

Sokol.ov, S. \& RinToul, S.R., 2000: Circulation of the southwest Pacific: WOCE section P11S. J. Mar. Res. 58.

Stommel, H. \& Arons, A.B., 1960: On the abyssal circulation of the world ocean - I. Stationary flow patterns on a sphere. Deep-Sea Res. I(6): 140-154.

Sundquist, E.T., 1993: The global carbon dioxide budget. Science 259: 934-941.

Sverdrur, H.U., 1933: On vertical circulation in the ocean due to the action of the wind with applications to conditions within the Antarctic Circumpolar Current. Discovery Rep. VII: $131-170$

Warren, B.A., LaCasce, J.H. \& Robbins, P.E., 1996: On the obscurantist physics of "form drag" in theorizing about the circumpolar current. J. Phys. Oceanogr. 26: 22972301. 
Warr.eN; B.A., LaCasce, J.H. \& Robbins, P.E., 1998: Reply to "Comments on 'On the obscurantist physics of "form drag" in theorizing about the circumpolar current'." J. Phys. Oceanogr. 28: 1655-1658.

Whit W. B. \& Peterson, R., 1996: An Antarctic Circumpolar Wave in surface pressure, wind, temperature and sea ice extent. Nature 380: 699-702.

WolfF, J.-O., Maier-Reimer, E. \& Olbers, D.J., 1991: Winddriven flow over topography in a zonal B-plane channel: A quasi-geostrophic model of the Antarctic Circumpolar Current. J. Phys. Oceanogr. 21: 236-264.
Wong, A.P.-K., Bindof, N.L. \& Church, J.A., 1999: Coherent large-scale decadal freshening of intermediate waters in the Pacific and Indian Oceans. Nature 400: 440-443.

Worthington, L.V., 1981: The water masses of the world ocean: Some results of a fine-scale census. In Warren, B.A. \& Wunsch, C. (Eds): EVOLUTION OF PHYSICAL OCEANOGRAPHY: SCIENTIFIC SURVEYS IN HONOR OF HENRY STOMMEL. MIT Press: Ch. 2, 42-69.

(accepted 5 July 1999) 